УДК 373. 2. 015. 31: 17. 022.1

DOI: $10.35619 /$ iiu.v2i11.256

\author{
Гурнік Людмила \\ доцент кафедри педагогіки, \\ психології та корекційної освіти \\ Рівненського обласного інституту \\ післядипломної педагогічної освіти, \\ м. Рівне, Україна \\ ORCID: 0000-0001-6618-5720 \\ e-mail: gurnik58@ukr.net
}

\title{
ФОРМУВАННЯ ДУХОВНО-МОРАЛЬНИХ ЦІННОСТЕЙ У ДОШКІЛЬНИКІВ
}

Анотація. Стаття присвячена проблемі формування духовно-моральних цінностей дошкільників. Проаналізовано погляди вітчизняних та зарубіжних вчених щодо змістового наповнення понять «духовність», «цінності». 3'ясовано, що духовно-моральні цінності пов'язані із сформованими гуманістичними якостями, зокрема, любов'ю, повагою, гідністю, турботою про інших, співпереживанням, взаємодопомогою, добром, дружбою, взаємопідтримкою, толерантністю, непримиренністю до проявів зла тощо. Цінності $\epsilon$ продуктом духовної культури, вони формуються і створюються в ході розвитку людської цивілізації, тому є загальноприйнятими і зберігаються в загальній культурній традиції. Вони виступають у якості орієнтира діяльності та існують у свідомості людини. Показником сформованих цінностей служать дії і вчинки, а не існуюча дійсність, і виявити їх можливо лише в дії.

Розглянуто освітньо-виховний процес закладу дошкільної освіти з позиції упровадження педагогіки підтримки зростаючої особистості, в основі якої - ціннісне ставлення до навколишньої дійсності та самого себе, що певною мірою спонукає до нового осмислення ролі педагога в освітньому процесі на основі суб'єкт-суб'єктної взаємодії і передбачає діалог, спільну участь в організації освітньо-виховного процесу, орієнтацію на кожну дитину як ціннісно зорієнтованої, життєво компетентної особистості.

Виокремлено мету, завдання, форми роботи з дошкільниками щодо формування в них духовно-моральних цінностей, що розкриваються у контексті реалізації напрямів виховання «Я і сім'я», «Я і природа», «Я і країна». Запропоновані форми і методи виховання відповідають віковим та індивідуальним особливостями дошкільнят, мотивовані на їх гуманізацію, ураховують особистий життєвий досвід дитини дошкільного віку, підвищують їх прагнення до активної співпраці і спрямовані на засвоєння духовних цінностей, норм $\mathrm{i}$ правил моральної поведінки у взаємодії з собою та іншими.

Ключові слова: духовно-моральні цінності, дошкільники, виховний процес закладу дошкільної освіти, концепти «Я і сім'я», «Я і природа», «Я і країна».

Постановка проблеми. Проблема формування духовно-моральних цінностей молодого покоління завжди була в центрі уваги філософів, педагогів, психологів, соціологів, вчителівпрактиків. Нестабільність і суперечливість моральної атмосфери в українському суспільстві підсилили проблему духовно-морального виховання підростаючого покоління.

Актуальність цієї проблеми відображена в низці нормативно-правових документів: Законах України «Про освіту», «Про дошкільну освіту», «Про загальну середню освіту», 
«Про позашкільну освіту», «Про захист суспільної моралі», Національній доктрині розвитку освіти України в XXI ст., Указі Президента України «Про заходи щодо розвитку духовності, захисту моралі та формування здорового способу життя громадян», Концепції виховання гуманістичних цінностей в учнів загальноосвітньої школи, Концепції Нова українська школа, Програмі «Нова українська школа у поступі до цінностей» та інших. Відповідно до їхнього змісту, духовно-моральне виховання дітей слід здійснювати на базі синтезу національних і духовних цінностей, забезпечуючи становлення громадянина-патріота України як духовно багатої особистості.

Аналіз останніх досліджень 3 проблеми. Педагогічні основи виховання у дітей духовно-морально цінностей українського народу розкрито в роботах О. Вишневського, Ю. Руденка, М. Стельмаховича, В. Сухомлинського.

Сучасні вітчизняні та зарубіжні дослідники проблему формування духовно-моральних цінностей розглядають як: цілеспрямований процес оволодіння дітьми системою узагальнених гуманних уявлень і понять (С. Литвиненко); засіб і метод морального виховання осіб, що грунтується на довільному сприйнятті нею морального виховання (I. Бех); духовний розвиток особистості (I. Бех, М. Боришевський, I. Зязюн, М. Савчин, С. Яремчук, С. Ярмусь ); турбота про інших та співпереживання (І. Дьоміна, М. Тимошенко); взаємодопомога та взаємопідтримка (А. Виноградова, Т. Поніманська, Т. Рєпіна); толерантність (Р. Валітова, Д. Зінов'єв, В. Лекторський); щоденна гуманна поведінка (Н. Цуканова). Головну роль у формуванні духовно-моральних цінностей В. Постовий, П. Щербань, Т. Алексєєнко, О. Докукіна, Н. Стрєльникова відводять сім’ї.

Проблему формування гуманістичних цінностей розкрито в наукових дослідження Ю. Бондаренка, М. Жулинського, М. Горди, Л. Драчук, В. Коваль, Р. Мовчана, А. Фасолі та ін. Вважаючи гуманістичні цінності складовою моральних або загальнолюдських, вони зосереджують увагу на формуванні гуманістичних якостей та гуманістичних цінностей зростаючої особистості, вихованні поваги до людини та іiі гідності, на проявах доброзичливості, співпереживання, милосердя, співчуття, непримиренності до проявів зла тощо.

Мета статті - розкрити сутність орієнтовних напрямів (концептів) виховної роботи вихователя дошкільного закладу освіти щодо формування в дошкільника духовноморальних цінностей.

Виклад основного матеріалу дослідження. Вивчення науково-педагогічної літератури 3 питань формування духовності, моральності у молодого покоління спонукає нас розкрити сутність поняття «духовність». В психолого-педагогічній літературі існують різні підходи до тлумачення цього поняття. Розглянемо їх.

Наприклад, А. Богуш у понятті «духовність» вбачає своєрідний інтелектуальночуттєвий, емоційний стан особистості, що виявляється в позитивній поведінці й діяльності людини та характеризує цілісність їі як особистості (Богуш, 2000, с.18-23.).

Академік І. Бех вважає, що духовність передбачає вихід за межі егоїстичних інтересів, особистої користі й зосередженість на моральній культурі людства (Бех, 2006).

О. Вишневський відносить духовність до абсолютних цінностей і пов'язує іiї зі шляхом людини до Бога, іiі зорієнтованістю на дотримання в житті Божих заповідей (Вишневський, 2008).

У розвитку духовності С. Яремчук перевагу надає праці, спрямованій на саморозвиток особистості, що допомагає людині стати Людиною і зберігає ії людяність (Яремчук, 2012).

У тлумаченні С. Ярмуся духовність тісно пов'язана із свідомою активністю людського духу, яка підносить людину до ідеалу добра, - до того, що їі облагороджує (Ярмусь, 2002). 
У Концепції виховання гуманістичних цінностей в учнів загальноосвітньої школи зазначається, що цінності - це узагальнені уявлення людей про цілі та норми своєї поведінки, що втілюють свій історичний досвід і концентровано виражають сенс культури епохи, певного суспільства в цілому, всього людства. Вони є продуктом духовної культури, формуються і створюються «в ході розвитку самої історії», в суспільно-історичній практиці, тому є загальноприйнятими і зберігаються в загальній культурній традиції. Тому цінності виступають орієнтиром у вихованні. Про це наголошується, зокрема, в Концепції Нова українська школа: «Духовно-ціннісний вимір освіти й виховання має спиратися на особистість як головну цінність навчально-виховного процесу» (Міністерство освіти і науки України, 2015).

Враховуючи виховний аспект дошкільної освіти, ми керуємося завданнями, зазначеними в Законі України «Про дошкільну освіту», а саме: «виховувати у дітей любов до України, шанобливе ставлення до родини, повагу до народних традицій і звичаїв, державної мови, регіональних мов або мов меншин та рідної мови, національних цінностей українського народу, а також цінностей інших націй і народів, свідоме ставлення до себе, оточення та довкілля» (Міністерство освіти і науки України, 2001).

У дошкільній освіті виховання розглядається як процес залучення дитини до системи вироблених людством цінностей, організація умов для їі духовного зростання, забезпечення адаптації дошкільника до навколишньої дійсності та його соціалізації.

3 огляду на це, в освітній процес закладу дошкільної освіти впроваджується нова філософія виховання - педагогіка підтримки зростаючої особистості, в основі якої - ціннісне ставлення до навколишньої дійсності та самого себе, яка спонукає до нового осмислення ролі педагога в освітньому процесі на основі суб'єкт-суб'єктної взаємодії, що передбачає діалог, спільну участь в організації освітнього процесу, орієнтацію на кожну дитину як ціннісно зорієнтованої, життєво компетентної особистості.

Для дітей дошкільного віку характерним є відсутність соціального та морального досвіду, але в той же час вони сприятливі до сприйняття морально-етичних впливів, бажання наслідувати поведінку інших. Моральні вчинки вихователя, батьків позитивно сприймаються дошкільнятами і слугують прикладом для наслідування.

Основні види діяльності дошкільників - спілкування та ігрова діяльність, які сприяють формуванню критичного мислення, що своєю чергою впливає на формування таких особистісних духовно-моральних якостей як добро, гуманність, відповідальність, людяність, милосердя, толерантність, чуйність, співчуття, чесність, справедливість, терплячість, а також моральних ставлень до таких категорій, як зло, неввічливість, грубість, жорстокість тощо.

Формування особистості молодшого школяра визначається реалізацією у виховному процесі особистісно зорієнтованого підходу, згідно з яким моральні правила та етичні норми дитина засвоює активно, послідовно і цілеспрямовано в процесі діяльності та спілкування 3 дорослими та однолітками. В результаті чого в неї формується позитивний досвід ставлення до самого себе, сім’ї, природи, країни, суспільства тощо. Під ставленням ми маємо на увазі цілісну систему індивідуальних, свідомих зв'язків особистості 3 різними сторонами об'єктивної дійсності, які визначаються особистісним мотивом.

Цінності не можуть нав'язуватися особистості, оскільки вони є індивідуальними, такими, якими їх бачить і розуміє сама особистість, як інтерпретує, враховуючи власний життєвий і моральний досвід. Тому важливим $є$ акцентувати увагу на формуванні ставлень дошкільника до самого себе, до сім’ї, народу, суспільства, природи. Показниками ставлення особистості є іï якості, які й несуть у собі цінності. 
Пропонуємо орієнтовні напрями роботи вихователя дошкільного закладу освіти (концепти) щодо формування в дошкільника духовно-моральних цінностей.

Я і сім'я. Сім'я - соціальна група, яка складається з людей, які зазвичай перебувають у шлюбі, їхніх дітей (власних або прийомних) та інших осіб, поєднаних родинними зв'язками 3 подружжям, кровних родичів, і здійснює свою життєдіяльність на основі спільного економічного, побутового, морально-психологічного укладу (Вікіпедія, сім'я). «Людина в своєму розвитку стає такою, яка в неї мати, точніше, яка гармонія любові і волі в іiі духовному світі» і «батько народжує і виражає, продовжує, розвиває себе в своєму синові й дочці, вливаючи своє духовне начало з духовним началом матері» (Сухомлинський, 1976).

Мета: виховання ціннісного ставлення до сім’ї і родини.

Завдання: формування любові і поваги до батьків, кровних родичів, мотивації до взаємодії та взаємопідтримки; встановлення єдності вимог закладу дошкільної освіти i батьків у вихованні дітей.

Форми і методи роботи: виставка малюнків «Портрет моєї мами», «Портрет мого тата»; привітання «Говорять діти»; проєкт «Дерево мого роду»; конкурси «Мамині помічники», «Татові помічники»; фотовиставка «Моя сім'я»; свята, ранки, презентації; перегляд та аналіз мультфільмів; батьківські збори 3 використанням презентацій «Як знайомити дітей 3 містом», «По дорозі в дитячий садочок», «Подорож у царство Доброти», година ввічливих малят; розвивальні ігри та вправи.

Очікувані результати: сформовані почуття любові, поваги до батьків, бажання завжди допомагати їм.

Я і природа. Природа - органічний і неорганічний світ у всій сукупності і зв'язків, що $є$ об'єктом людської діяльності і пізнання, все те, що не створене людською діяльністю (Великий тлумачний словник сучасної української мови, 2001). Природа - не безмежний склад, запаси її вичерпні, тому діяльність людини в природі повинна бути розумною.

Мета: виховання ціннісного ставлення до природи, усього живого.

Завдання: формування у дітей наукових знань про різні явища навколишньої природи в поєднанні з розумінням цінності природи для суспільства і людини; оволодіння нормами поведінки в природному середовищі; виховання дбайливого ставлення до живих істот.

Форми $і$ методи роботи: акції «Затишний будинок кожному!», «Посади дерево!», «Чисте місто», «Нагодуймо птахів взимку!», «Паперовий бум!»; операція «Чисте місце для роботи»; мовленнєві, настільні та сюжетно-рольові ігри; проєкти, загадки, вікторини; розвивальні ігри та вправи.

Очікувані результати: оволодіння екологічними знаннями і вміннями, бажання активно захищати та покращувати природне середовище.

Я і країна. Країна - це територія 3 визначеними кордонами й населенням, що являє собою єдине ціле з погляду історії, культури, нації та в політико-географічному відношенні може бути незалежною або залежною (Вікіпедія, країна). Дбайливе ставлення до своєї історії, усвідомлення важливості іiі збереження, формування моральних цінностей i моральних підвалин необхідно виховувати 3 раннього віку і дошкільне дитинство $\epsilon$ початковим етапом формування особистості людини. В цей же час закладається позитивне ставлення до історії міста (села), до пам'яток, до себе і навколишніх людей.

Мета: виховання ціннісного ставлення до міста (села), краю, країни.

Завдання: ознайомлення дітей з історією і сучасністю міста (села); формування у дітей уявлень про його жителів; розвиток прагнення знати своє місто; формування патріотизму і гордості за Батьківщину. 
Форми $і$ методи роботи: символи і символіка краю та країни; проєкт «7 чудес міста Рівне»; книжки-саморобки «Моя вулиця. Вулиці мого міста (села)», «Пам’ятники мого міста»; вікторина «Де знаходиться пам'ятник?», «Дізнайся за описом», «Хто що робить»; конкурси «Знавці Рівного», «Моє місто (село)», «Моя адреса»; фотовиставки «Ми жителі нашого міста (села)», «Вулиця, на якій я живу»; сезонні виставки дитячих робіт, виконаних у співтворчості з батьками: «Моє улюблене місто», «Місто очима дитини»; розвивальні ігри та вправи.

Очікувані результати: сформовані патріотичні почуття та ціннісні ставлення до малої та великої Батьківщини; почуття любові і гордості за жителів міста (села); розвинений громадянський патріотизм.

Досвід практичної роботи підтверджує, чим активніше дитину залучають до участі в різних формах виховної роботи, тим краще вона засвоює національні особливості свого народу, його культуру, мову, тобто ціннісні орієнтації. При цьому спочатку виявляється усвідомлення їх сутності, а вже потім внутрішня потреба в дотриманні й використанні норм та правил ціннісних ставлень та поведінки.

Висновки та перспективи подальших розвідок. Дошкільний вік $є$ сприятливим для формування духовно-моральних цінностей. У процесі цілеспрямованої виховної діяльності, дошкільники засвоюють духовні цінності, норми і правила моральної поведінки у взаємодії з собою та іншими. Форми і методи виховання мають відповідати віковим та індивідуальним особливостями дошкільнят, бути мотивованими на їх гуманізацію, враховувати особистий життєвий досвід дитини дошкільного віку, підвищувати їх бажання до активної співпраці.

Перспективу подальших наукових розвідок вбачаємо у розробці основних конструктів виховного простору дошкільника.

\section{СПИСОК ВИКОРИСТАНИХ ДЖЕРЕЛ}

Богуш, А. (2000). Дефініції «духовність» і «моральність» в аспекті національного виховання в Україні. Морально-духовний розвиток особистості в сучасних умовах: збірник наукових праць. Київ, Кн.1, с.18-23.

Бех, І. (2006). Виховання особистості : Сходження до духовності. Київ: Либідь. 272 с.

Вишневський, О. (2008). Теоретичні основи сучасної української педагогіки : навчальний посібник. 3-тє вид., доопрац. і доп. Київ: Знання. 566 с.

Яремчук, С. (2012). Проблема духовності в процесі професійної підготовки майбутніх педагогів. Збірник наукових пращь Інституту психології імені Г.С. Костюка Начіональної АПН України / за ред. С.Д. Максименка. Київ, Т. ХIV. Ч.1. С. 397-404.

Ярмусь, С. (2002). Досвід віри україния : Вибрані твори / упорядн. А. Колодний. Київ: Світ знань. 512 с.

Бех, І., Ганнусенко, Н., Чорна, К. (2005). Концеепџія виховання гуманістичних цүінностей в учнів загальноосвітньої школи. URL: http://dspace.nbuv.gov.ua/bitstream/handle/123456789/43932/2005_36_61.pdf?sequence=1

[Дата звернення 10.04.2020p.]

Міністерство освіти і науки України (2001). Концепція «Нова українська школа» (2015) http: // mon.gov.ua/ activity/education/zagalna-serednya/ua-sch-2016/konczepcziya.html [Дата звернення 10.04.2020p.]

Міністерство освіти і науки України (2001). Закон України «Про дошкільну освіту. URL: https://zakon.rada.gov.ua/laws/show/2628-14 [Дата звернення 10.04.2020p.] 
Міністерство освіти і науки України (2018). Програма «Нова Украӥнська школа»у nоступі до иінностей». URL: https://ru.calameo.com/read/004064295569365eba3d5. [Дата звернення 10.04.2020p.]

Вікіпедія. Сім'я. URL: https://www.google.com/search?q=сім"я\%20 [Дата звернення 10.04.2020p.]

Сухомлинський В. Вибрані твори: у 5 т. Т. 2. Київ: Рад. школа, 1976. 521 с.

Великий тлумачний словник сучасної украӥнської мови (2001). / уклад. і гол. ред. В. Т. Бусел. Київ; Ірпінь : Перун, 1440 с.

Вікіпедія. Краӥна. URL: https://uk.wikipedia.org/wiki/Країна [Дата звернення 10.04.2020p.]

\section{REFERENCES}

Bohush, A. (2000). Definitsii «dukhovnist» i «moralnist»v aspekti natsionalnoho vykhovannia v Ukraini [Definitions "Spirituality" and "Morality" in the Aspect of National Education in Ukraine]. Moralno-dukhovnyi rozvytok osobystosti v suchasnykh umovakh : zbirnyk naukovykh prats. Kyiv. Kn.1. S.18-23 (in Ukrainian).

Bekh, I. (2006). Vykhovannia osobystosti : Skhodzhennia do dukhovnosti. [Education of the Personality: Ascension to Spirituality]. Kyiv: Lybid. 272 s. (in Ukrainian).

Vyshnevskyi, O. (2008). Teoretychni osnovy suchasnoi ukrainskoi pedahohiky : navchalnyi posibnyk [Theoretical Foundations of Modern Ukrainian Pedagogy: textbook]. 3-tie vyd., dooprats. i dop. Kyiv: Znannia. 566 s. (in Ukrainian).

Yaremchuk, S. (2012). Problema dukhovnosti v protsesi profesiinoi pidhotovky maibutnikh pedahohiv [The Problem of Spirituality in the Process of Professional Training of Future Teachers]. Zbirnyk naukovykh prats Instytutu psykholohii imeni H.S. Kostiuka Natsionalnoi APN Ukrainy / za red. S.D. Maksymenka. Kyiv, T. KhIV. Ch.1. S. 397-404. (in Ukrainian).

Yarmus, S. (2002). Dosvid viry ukraintsia : Vybrani tvory [Experience of Ukrainian Faith: Selected Works] / uporiadn. A. Kolodnyi. Kyiv : Svit znan. 512 s. (in Ukrainian).

Bekh, I., Hannusenko, N., Chorna, K. (2005). Kontseptsiia vykhovannia humanistychnykh tsinnostei $v$ uchniv zahalnoosvitnoi shkoly [The Concept of Education of Humanistic Values for Students of Secondary School]. http://dspace.nbuv.gov.ua/bitstream/handle/123456789/43932/2005_36_61.pdf?sequence=1

[Data zvernennia 10.04.2020 r.] (in Ukrainian).

Ministerstvo osvity i nauky Ukrainy (2001). Kontseptsiia «Nova ukrainska shkola» (2015), [Concept "The New Ukrainian School”]. URL: http: // mon.gov.ua/ activity/education/zagalnaserednya/ua-sch-2016/konczepcziya.html [Data zvernennia 10.04.2020r.] (in Ukrainian).

Ministerstvo osvity i nauky Ukrainy (2001). Zakon Ukrainy «Pro doshkilnu osvitu [Law of Ukraine "On Preschool Education]. URL: https://zakon.rada.gov.ua/laws/show/2628-14 [Data ostannoho zvernennia 10.04.2020r.] (in Ukrainian).

Ministerstvo osvity i nauky Ukrainy (2018). Prohrama «Nova Ukrainska shkola» u postupi do tsinnostei». [Programme "The New Ukrainian School and the Development of Values] URL: https://ru.calameo.com/read/004064295569365eba3d5. [Data zvernennia 10.04.2020 r.] (in Ukrainian).

Vikipediia. Simia [Wikipediia. Family] URL: https://www.google.com/search?q=sim"ia\%20 [Data zvernennia 10.04.2020 r.] (in Ukrainian).

Sukhomlynskyi V.O. Vybrani tvory: u 5 t. T. 2. [Selected Works: in 5 volumes. Vol. 2]. Kyiv : Rad. shkola, 1976. 521 s. (in Ukrainian). 
Velykyi tlumachnyi slovnyk suchasnoi ukrainskoi movy (2001) [Great Explanatory Dictionary of the Modern Ukrainian Language]. / uklad. i hol. red. V. T. Busel. Kyiv; Irpin : Perun, $1440 \mathrm{~s}$. (in Ukrainian).

Vikipediia. Kraina \{Wikipediia. Country]. URL: https://uk.wikipedia.org/wiki/Kraina [Data zvernennia 10.04.2020 r.] (in Ukrainian).

\title{
FORMATION OF SPIRITUAL AND MORAL VALUES IN PRESCHOOL CHILDREN
}

\author{
Liudmyla Hurnik \\ Associate Professor at the Department of \\ Pedagogy, Psychology and Correctional Education, \\ Rivne Regional Institute of \\ Postgraduate Teacher Education, \\ Rivne, Ukraine \\ ORCID: 0000-0001-6618-5720 \\ e-mail:gurnik58@ukr.net
}

\begin{abstract}
The article is devoted to the problem of formation of spiritual and moral values in preschool children. The views of Ukrainian and foreign scholars on the content of the concepts "spirituality", "values" were analyzed.

It was revealed that spiritual and moral values are connected with such formed humanistic qualities as love, respect, dignity, concern for others, empathy, mutual help, goodness, friendship, mutual support, tolerance, other human qualities etc. Values as a product of spiritual culture are formed and created in the course of the development of human civilization, so they are accepted and preserved in the common cultural tradition. Values act as a guideline for the activities that exist in the human mind. Actions and deeds, rather than the existing reality, are an indicator of prevailing values, so they can be identified only in action. Educational process of the institution of preschool education is considered from the perspective of the implementation of pedagogy of supporting the young personality, which is based on a value attitude to the surrounding reality and to himself, which in turn leads to a new understanding of the role of the teacher in the educational process on the basis of subject-subjective interaction, which involves dialogue, common participation in the organization of the educational process, orientation to each child as a value-oriented, life-competent personality.

The purpose, tasks, forms of work with preschool children in the context of shaping spiritual and moral values were distinguished ; they were disclosed in the context of the implementation of concepts of upbringing "Me and family", "Me and nature", "Me and country".

The offered forms and methods of education correspond to the age and individual characteristics of preschool children, they are motivated at their humanization, take into account the personal life experience of the child of preschool age, increase their desire for active cooperation and are aimed at assimilation of spiritual values, norms and rules of moral behavior and interaction.

Keywords: spiritual and moral values, preschool children, educational process of the institution of preschool education, concepts "Me and family", "Me and nature", "Me and my country".
\end{abstract}

